\section{Horticultural Characterization of Wild Hydrangea quercifolia Seedlings Collected Throughout the Species Native Range}

\author{
Andrew Sherwood \\ USDA-ARS North Central Regional Plant Introduction Station, 1305 \\ State Avenue, Ames, IA 50014
}

Lisa W. Alexander

USDA-ARS U.S. National Arboretum, Otis L. Floyd Nursery Research Center, 472 Cadillac Lane, McMinnville, TN 37110

\author{
Matthew D. Clark \\ Department of Horticultural Science, University of Minnesota, 342 Alderman \\ Hall, 1970 Folwell Avenue, Saint Paul, MN 55108
}

\section{Steve McNamara \\ Horticultural Research Center, University of Minnesota, 600 Arboretum Boulevard, Excelsior, MN 55331}

\author{
Stan C. Hokanson \\ Department of Horticultural Science, University of Minnesota, 258 \\ Alderman Hall, 1970 Folwell Avenue, Saint Paul, MN 55108
}

Additional index words. cold hardiness, disease resistance, germplasm characterization, oak leaf hydrangea, plant architecture

\begin{abstract}
Oakleaf hydrangea (Hydrangea quercifolia Bartr.) is an understory shrub native to the southeastern United States. Hydrangeas are popular ornamental landscape plants; however, little is known about the diversity in horticulturally important traits for oakleaf hydrangea. Information regarding the variation in important traits could guide future breeding efforts for the species. Seed was collected from 55 populations throughout the range of the species for the purpose of conducting a horticultural characterization of the species compared with select cultivars. Plant architecture was characterized as plant height, number of nodes, internode length, number of branches, and plant width. Plant architecture was measured for container-grown and field-grown plants in two locations (Minnesota and Tennessee). Tolerance to leaf spot (Xanthomonas campestris L.) was characterized for wild-collected seedlings and cultivars by measuring disease severity under exposure to ambient inoculum. Cold hardiness was characterized during two winters with a controlled freezing experiment. During the first winter, seedlings were tested in January; during the second winter, seedlings and cultivars were tested monthly from October through April. Plant architecture varied by environment, with plants growing larger in Tennessee than in Minnesota. The heights of container-grown and field-grown plants were correlated with the collection site latitude $(r=-0.66)$, with populations from the northeastern extent of the range of the species being the most compact, and populations from Florida being the tallest. Leaf spot severity varied significantly among populations and cultivars and was also correlated with latitude for the seedlings $(r=0.70)$. Two populations in Florida were identified as sources of high tolerance to leaf spot, whereas 'Flemygea' and 'Alice' were identified as having moderate tolerance to leaf spot. Cold hardiness varied among populations and cultivars and among months of the winter. The overall maximum cold hardiness was observed in February [mean lethal temperature $\left(\mathbf{L T}_{50}\right)=-33.7^{\circ} \mathrm{C}$ ], and several populations maintained an extreme level of cold hardiness into late winter. Midwinter cold hardiness also varied by latitude $(r=-\mathbf{0 . 6 5})$, with northern populations showing higher levels of cold hardiness. These results indicate that certain wild oakleaf hydrangea populations will be useful for introgressing novel variation into breeding programs.
\end{abstract}

Hydrangea L. is a popular genus of flowering plants that has high ornamental value and is often grown as a landscape plant. Several species of Hydrangea are grown for their

horticultural value, with $H$. macrophylla Thunb. being the most popular (Dirr, 2004). Despite recent interest in developing new hydrangea cultivars, $H$. quercifolia Bartr. (oakleaf hydrangea) remains a comparatively underused species, and very little genetic or horticultural information regarding the species is available.

Plant breeders rarely begin a new breeding program with a comprehensive evaluation of the species of interest; instead, they begin with germplasm (typically cultivars) that is most readily available (Van Laere et al., 2018a, 2018b). However, a systematic evaluation of wild germplasm before breeding would allow one to determine the full extent of variation for traits of interest, thereby allowing for selection of the best germplasm to begin the breeding process. Breeding of $H$. quercifolia is relatively recent, with only a few cultivars that have known pedigrees available (Reed, 2010; Reed and Alexander, 2015). Additionally, the native range of the species is relatively small in the southeastern United States, making it amenable to thorough sampling (Fig. 1). Therefore, the opportunity exists to conduct such a horticultural characterization of oakleaf hydrangea to further inform future breeding efforts.

Oakleaf hydrangea is a multistem shrub that can spread by branch layering. Traits related to plant architecture are important for oakleaf hydrangea because plants can attain heights more than $3 \mathrm{~m}$. Despite the increasing demand for compact genotypes of ornamental plants, there are very few available for $H$. quercifolia (Dirr, 2004). Additionally, the few that are available have been derived from the same two cultivars, Pee Wee and Sike's Dwarf (Reed, 2010; Reed and Alexander, 2015). Therefore, novel sources of compactness would contribute to generating new compact varieties while maintaining a wide genetic base.

Plant architecture of shrubs is a multicomponent trait that can be quantified in various ways (Crespel et al., 2012, 2013). An important component of plant architecture includes the total size of the plant, which is measured as height and width. The number of branches and internode length impact how compact a plant is visually, because even a relatively tall plant that is highly branched with small internodes can appear compact (Van Iersel and Nemali, 2004).

Oakleaf hydrangea is susceptible to a bacterial leaf spot disease caused by Xanthomonas campestris L. (Hagan and Mullen, 2001; Mmbaga and Oliver, 2007). Leaf spot causes unsightly lesions on the leaf that greatly diminish the ornamental quality of plants and likely reduce the fitness of wild plants. Leaf spot severity is especially high under production conditions that use overhead irrigation, thereby decreasing the value of the product (Hagan and Mullen, 2001). There is currently no known source of leaf spot tolerance for oakleaf hydrangea; therefore, identifying variation in tolerance to leaf spot would introduce the possibility of breeding for it. Tolerance to $X$. campestris has been found in species of other genera (Hayes et al., 2014; Maas et al., 2000; Naqvi et al., 2012) by screening diverse germplasm. 


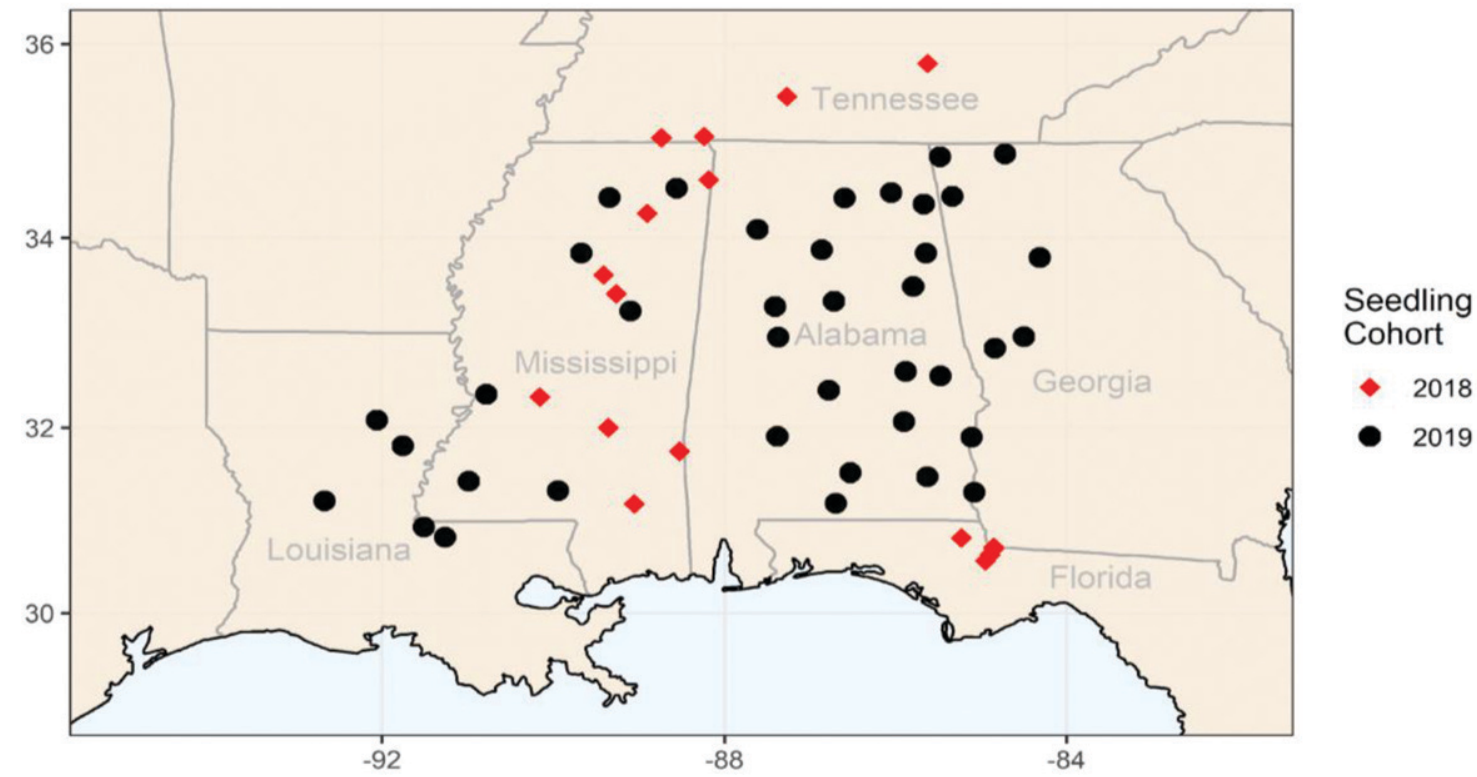

Fig. 1. Map depicting locations of Hydrangea quercifolia seedling cohorts collected for the study. Red diamonds indicate locations of seed collected in 2017 and germinated in 2018 (older cohort). Black circles indicate locations of seed collected in 2018 and germinated in 2019 (younger cohort). X-axis and Yaxis represent longitude and latitude, respectively.

Cold hardiness is a complex trait that limits the northern extent where oakleaf hydrangea can be grown in landscapes. Published estimates of the cold hardiness of oakleaf hydrangea are USDA Plant Hardiness Zone 5a $\left(-28.9\right.$ to $\left.-26.1^{\circ} \mathrm{C}\right)$ (Halcomb and Reed, 2012) (USDA Plant Hardiness Zone Map, 2012). However, this estimate is supported by testing only two cultivars (Dirr et al., 1993); therefore, it is unknown how much, if any, variation exists for cold hardiness of the species. In wild populations of woody plants, cold hardiness has been found to vary by latitude of origin (Aldrete et al., 2008; Hurme et al., 1997; Pagter et al., 2010); therefore, we hypothesized that northern $H$. quercifolia populations could be a source of increased cold hardiness. Cold hardiness of woody plants varies throughout the winter; however, the plant undergoes a process of acclimation (increasing hardiness) in the fall and deacclimation (decreasing hardiness) in the spring (Arora and Rowland, 2011). Temperate woody plants obtain maximum cold hardiness during midwinter. Assessing their hardiness at that time can provide a useful preliminary estimate of the ability of the plant to withstand cold temperatures. However, unseasonably late cold periods after the plant has begun to deacclimate can result in similar, or greater, winter damage than midwinter

Received for publication 2 Apr. 2021. Accepted for publication 23 May 2021.

Published online 16 August 2021.

Funding was received from the USDA-NPGS Germplasm Exploration and Collection Grant and the USDA-NPGS Germplasm Characterization Grant.

S.C.H. is the corresponding author. E-mail: hokan017@umn.edu.

This is an open access article distributed under the CC BY-NC-ND license (https://creativecommons. org/licenses/by-nc-nd/4.0/). extreme cold events. Pagter et al. (2011a) demonstrated that midwinter hardiness and deacclimation timing are different traits for Hydrangea; therefore, both need to be tested to gain the best understanding of the ability of the plant to survive winter. Dirr et al. (1993) found that 'Alice' and 'Alison' had the same cold hardiness in midwinter but deacclimated at different times, suggesting that variation exists for deacclimation timing in $H$. quercifolia.

The goal of this study was to characterize the phenotypic diversity of several key horticultural traits of wild Hydrangea quercifolia collected throughout the entire native range of the species. The traits analyzed included plant architecture (including plant height and width, number of stems and nodes, and internode length) of container-grown and fieldgrown plants, tolerance to bacterial leaf spot (Xanthomonas campestris), and cold hardiness throughout winter.

\section{Methods and Materials}

Plant material. Seeds were collected from 530 maternal plants from 55 wild $H$. quercifolia populations representing the complete natural range of the species from October to December in 2017 and 2018 (Fig. 1). For the purposes of this study, a population was defined as a semi-continuous group of hydrangeas at a sampling location being separated by a minimum of $2 \mathrm{~km}$ from the next nearest population. Permits were obtained from all landowners/managers before collection. The number of seed samples per population ranged from 1 to 29 , with each seed sample consisting of one open-pollinated inflorescence from one maternal plant (mean = 24,771 seeds per sample). Because $H$. quercifolia is self-incompatible (Reed, 2000, 2004), each sample was considered to be a maternal half-sibling family. Each sample was at least $10 \mathrm{~m}$ from the closest sample to avoid the possibility of sampling the same genet multiple times. Latitude and longitude were recorded for each maternal plant using EpiCollect5 (v3.0.3), which has a 10-m accuracy. Each inflorescence was placed in a plastic bag for transport to the laboratory. After drying, seed was extracted from each inflorescence and stored at $-20^{\circ} \mathrm{C}$ until sowing. The seeds were sown during Spring 2018 and Spring 2019, with each cohort consisting of the seed from the populations that were sampled during the previous fall (Fig. 1). In 2018, seed from 17 populations were grown (older cohort) and represented the latitudinal range of the species from Tennessee, Mississippi, and Florida. In 2019, seeds were grown (younger cohort) from 38 populations that covered the remaining geographical range including Louisiana, Georgia, and Alabama.

In 2018, seed was germinated under two conditions, in a greenhouse in Minnesota and in a growth chamber in Tennessee. Seed from each maternal parent was surface-sown onto a soilless germination mix (Sungrow Horticulture, Agawam, MA). In the greenhouse, flats were placed on heat mats (Hydrofarm Horticulture, Petaluma, CA) and covered with clear plastic domes to maintain high relative humidity. Greenhouse temperatures were maintained between 25 and $30^{\circ} \mathrm{C}$ with natural daylength. In 2019 , seeds were only germinated in the greenhouse in Minnesota under the same conditions described for 2018. During both years, the number of seed sown per half-sibling family and population varied based on the number of seed available.

After germination, seedlings were transplanted into $7.62-\mathrm{cm}$ square pots holding a soilless potting medium (Sungrow Horticulture, Agawam, MA) and grown in the 
Table 1. Hydrangea quercifolia cultivars used for leaf spot severity and cold hardiness screening tests. Leaf spot values represent the percent leaf area affected by Xanthomonas campestris on plants exposed to natural inoculum. Mean lethal temperature $\left(\mathrm{LT}_{50}\right)$ values represent the temperature at which $50 \%$ of the stem samples for a cultivar (4-6 replications per temperature per month) were killed during laboratory-based controlled freezer testing during Winter 2019-20.

\begin{tabular}{lcccccccc}
\hline & & \multicolumn{7}{c}{ Monthly $\mathrm{LT}_{50}\left({ }^{\circ} \mathrm{C}\right)$} \\
\cline { 3 - 9 } Cultivar & Leaf spot $(\%)$ & Oct. & Nov. & Dec. & Jan. & Feb. & Mar. & Apr. \\
\hline Alice & 8.8 & -8.3 & -26.0 & -30.6 & -35.0 & -31.2 & -22.7 & $0.0^{\mathrm{y}}$ \\
Brido & 14.3 & -13.7 & -29.9 & -32.8 & -33.2 & -35.1 & -27.4 & -19.7 \\
Brother Edward & - & - & - & - & -31.9 & - & - & - \\
Flemygea & 8.8 & -13.8 & -26.1 & -29.3 & -30.5 & -29.3 & -18.0 & $0.0^{\mathrm{y}}$ \\
Harmony & 14.0 & -9.6 & - & - & -32.9 & -35.4 & -17.1 & $0.0^{\mathrm{y}}$ \\
Munchkin & - & -13.6 & -26.8 & - & -32.0 & -33.2 & -26.7 & $0.0^{\mathrm{y}}$ \\
Pee Wee & 20.3 & -14.0 & -30.0 & -30.0 & -31.6 & -34.1 & $-15.0^{\mathrm{z}}$ & $0.0^{\mathrm{y}}$ \\
Queen of Hearts & 24.2 & -12.2 & -29.2 & -34.0 & -31.2 & -37.1 & -17.3 & -2.0 \\
Ruby Slippers & - & -13.7 & -25.6 & -31.0 & -31.9 & -33.6 & -30.7 & $-25.0^{\mathrm{z}}$ \\
Sike's Dwarf & 21.0 & $-15.0^{\mathrm{z}}$ & -28.8 & -35.5 & -36.9 & -37.7 & -28.7 & $0.0^{\mathrm{y}}$ \\
\hline
\end{tabular}

${ }^{\mathrm{z}}$ Less than $50 \%$ of stem samples were killed at the coldest temperature tested. The temperature listed is the coldest temperature tested.

${ }^{\mathrm{y}}$ More than $50 \%$ of stem samples were killed at the warmest temperature tested. The temperature listed is the warmest temperature tested.

Dashes (-) indicate the cultivar was not analyzed for leaf spot or for cold hardiness during that month.

greenhouse until May or June in 2018 and 2019, respectively. Greenhouse temperatures were maintained between 25 and $30^{\circ} \mathrm{C}$ with natural daylength. Seedlings were transplanted into $186.7-\mathrm{cm}^{3}$ square pots with peat:pine bark $(1: 1)$ potting mix and transferred to an outdoor container nursery with overhead irrigation. Plants were watered as needed throughout the growing season.

During Spring 2019, plants in the older cohort were cut back to three nodes above the soil to induce branching in their second year of growth. Cutting the plants back also served to equalize plant height at the beginning of the second growing season. Then, they were randomly assigned to three treatments, transplanted into 7.57-L containers, and planted in the field at the Horticulture Research Center in Chanhassen, MN (44.859, -93.634) or in the field at the Otis L. Floyd Nursery Research Center in McMinnville, TN (35.709, -85.744) using a completely randomized experimental design. Natural rainfall was supplemented with drip irrigation at both locations to prevent soil moisture deficits.

Cultivars (Table 1) were obtained from commercial nurseries in 2019 and grown under the same conditions as the wild-collected seedlings in 7.57-L pots. The plants were purchased as 2-year-old plants and were all approximately the same size on delivery. These plants were used for leaf spot tolerance assessment and cold hardiness testing.

Plant architecture. In 2018, a minimum of 100 random seedlings from each population (older cohort) were evaluated after terminal buds had set at the end of the growing season. Because plants were completely randomized within the container nursery, random sampling was achieved by measuring the first 100 seedlings located in each population. Plants were measured from the top of the soil to the top of the apical bud on the tallest shoot, and nodes were counted on the same shoots. Internode length was estimated by dividing the total height by the number of nodes.
In 2019, seedlings from both cohorts were measured using the same methods used in 2018. Seedlings in the older cohort were measured in 7.57-L pots and in both field locations (Minnesota and Tennessee) to assess genotype $\times$ environment interactions. In addition to the traits measured in 2018, the number of primary branches was also measured in the older cohort in 2019. Because of the lack of secondary branches, branch counts were unambiguous. Additionally, the canopy width was measured in the field by averaging the width in the widest dimension and the width perpendicular to the widest dimension. Means for each population and environment were assessed with an analysis of variance (ANOVA) and Bonferroni-corrected for multiple comparisons. All statistical analyses were conducted using R (R Core Team, 2018).

Leaf spot tolerance. In Sept. 2019, leaves were sampled from 100 seedlings randomly
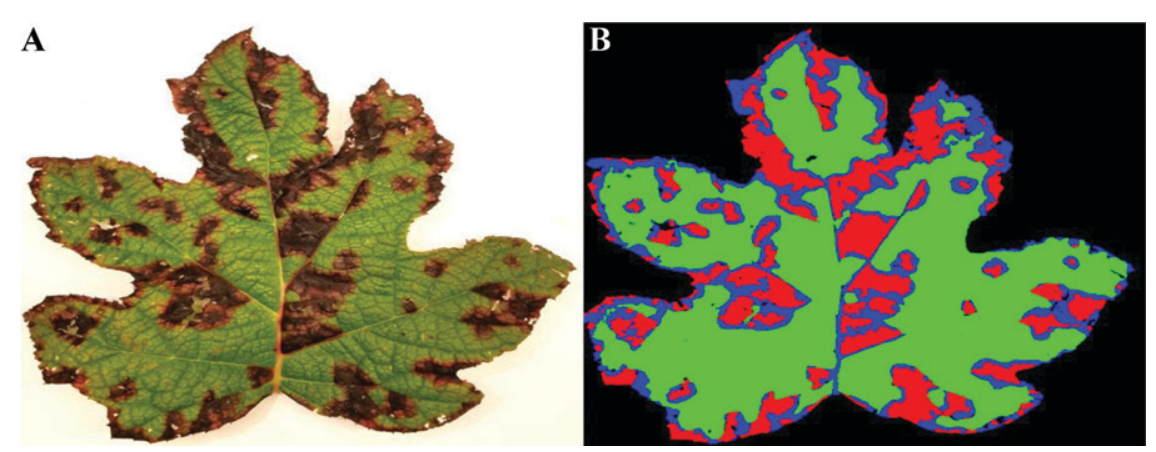

Fig. 2. Example of leaf spot incited by Xanthomonas campestris and image analysis of the affected Hydrangea quercifolia leaf. (A) Image of leaf exhibiting leaf spot. (B) Image segmented into background pixels (black), healthy leaf (green), necrotic tissue (red), and discoloration (blue).

Table 2. Beginning and end temperatures and the temperature interval decrease (number of degrees between test temperatures) used each month for each treatment for controlled freezing experiments conducted during Winter 2019-20.

\begin{tabular}{lrrrrrrr}
\hline & Oct. & Nov. & Dec. & Jan. & Feb. & Mar. & Apr. \\
\hline High temperature $\left({ }^{\circ} \mathrm{C}\right)$ & 0 & -10 & -20 & -20 & -20 & -15 & 0 \\
Low temperature $\left({ }^{\circ} \mathrm{C}\right)$ & -15 & -30 & -40 & -40 & -40 & -35 & -25 \\
Interval $\left({ }^{\circ} \mathrm{C}\right)$ & -3 & -4 & -4 & -4 & -4 & -4 & -5 \\
\hline
\end{tabular}
and secondary symptoms. This software selected from each population within the older cohort in Minnesota or from 10 plants per cultivar. One leaf was sampled per seedling and three leaves were sampled per culti$L$ pots. Plants occurring $X$. campestris inoculum under container nursery conditions including overhead irrigation. Populations were completely randomized within the nursery to ensure equivalent exposure to inoculum. The fourth fully expanded leaf was chosen for sampling based on the observation that the leaf spot symptoms were less severe on the top of the canopy, whereas leaves further down in the canopy were severely senesced or otherwise deteriorated. Leaves were immediately transported to the laboratory for imaging against a white background with uniform, cool white fluorescent lighting. Images were obtained with a Samsung SM-G950U1 camera (Samsung Electronics Co., Seoul, South Korea) with 4032- $\times$ 3024-pixel resolution, a $4.25-\mathrm{mm}$ focal length and saved in the .jpg file format.

Images were analyzed using Food Color Inspector software (v4.0; http://www.cofilab. $\mathrm{com} /$ portfolio/food-color-inspector/) to determine the percent leaf area affected by lesions allows the user to define each of the catego-
ries in a training set; then, it assigns all pixels in the image to one of the categories based on the color using a Bayesian algorithm. One leaf per population was used as the initial training set for the population, which was iteratively as needed for each leaf to assigned to four categories: background; healthy leaf tissue; necrotic leaf tissue; and discolored leaf tissue (Fig. 2). Discoloration was either chlorosis or other impacted tissue surrounding or immediately adjacent to necrotic tissue; it typically represented the leading edge of the lesion. The percent leaf 
Table 3. Population means for traits measured in wild-collected Hydrangea quercifolia seedlings. Leaf spot values represent the percent leaf area affected by Xanthomonas campestris on plants exposed to natural inoculum. The mean lethal temperature (LT 50$)$ values represent the temperature at which $50 \%$ of the stem samples for a population were killed during laboratory-based controlled freezer testing (8-12 stem samples per population per temperature).

\begin{tabular}{|c|c|c|c|c|c|c|c|c|c|c|}
\hline $\begin{array}{l}\text { Population } \\
\text { ID }\end{array}$ & State & $\begin{array}{c}\text { Seed } \\
\text { sown }(y r)\end{array}$ & $\begin{array}{c}\text { Leaf } \\
\text { spot }(\%)\end{array}$ & $\mathrm{Ht}\left(\mathrm{cm}^{\mathrm{z}}\right)$ & $\begin{array}{c}\text { Node } \\
\text { no. }^{z}\end{array}$ & $\begin{array}{c}\text { Internode } \\
\text { length }\left(\mathrm{cm}^{\mathrm{zy}}\right)\end{array}$ & Branch no. ${ }^{\mathrm{z}}$ & $\begin{array}{l}\text { Width } \\
\left(\mathrm{cm}^{\mathrm{zx}}\right)\end{array}$ & $\mathrm{LT}_{50}\left({ }^{\circ} \mathrm{C}^{\mathrm{z}}\right)$ & $\begin{array}{c}\text { Winter } \\
\text { damage }^{\mathrm{w}}\end{array}$ \\
\hline$\overline{2}$ & FL & 2018 & 3.5 & 60.4 & 10.2 & 5.4 & 3.9 & 16.4 & - & 2.5 \\
\hline 3 & $\mathrm{FL}$ & 2018 & 3.7 & 56.4 & 10.7 & 5.8 & 4.1 & 31.4 & -27.8 & 2.5 \\
\hline 4 & FL & 2018 & 9.9 & 57.7 & 11.1 & 5.3 & 4.4 & 33.3 & -26.9 & 3.1 \\
\hline 5 & FL & 2018 & 9.5 & 59.1 & 10.6 & 5.8 & 4.0 & 26.3 & - & 2.8 \\
\hline 6 & FL & 2018 & 10.3 & 49.0 & 10.0 & 4.7 & 4.8 & 31.2 & -27.9 & 3.8 \\
\hline 8 & AL & 2019 & - & 32.5 & 6.8 & 4.7 & - & - & -38.7 & - \\
\hline 9 & AL & 2019 & - & 29.0 & 6.6 & 4.2 & - & - & $-35.0^{\mathrm{v}}$ & - \\
\hline 10 & AL & 2019 & - & 25.9 & 6.1 & 4.0 & - & - & -36.4 & - \\
\hline 11 & $\mathrm{TN}$ & 2018 & 10.6 & 53.0 & 10.8 & 4.6 & 3.9 & 23.7 & -31.6 & 4.6 \\
\hline 12 & $\mathrm{TN}$ & 2018 & 19.2 & 41.5 & 9.1 & 4.2 & 4.5 & 15.8 & -31.1 & 4.7 \\
\hline 13 & $\mathrm{TN}$ & 2018 & 13.3 & 37.8 & 8.9 & 4.3 & 3.6 & 12.6 & -29.6 & 5.0 \\
\hline 14 & $\mathrm{TN}$ & 2018 & 26.5 & 36.0 & 8.4 & 4.0 & 4.5 & 14.1 & -34.1 & 4.9 \\
\hline 16 & MS & 2018 & 14.8 & 48.8 & 10.9 & 4.4 & 4.4 & 25.5 & -32.7 & 4.0 \\
\hline 17 & MS & 2018 & 19.8 & 52.4 & 11.2 & 4.3 & 4.3 & 25.3 & -30.5 & 4.7 \\
\hline 18 & MS & 2018 & 16.5 & 52.2 & 10.2 & 4.8 & 3.8 & 17.9 & -30.5 & 4.2 \\
\hline 19 & MS & 2018 & 13.8 & 52.2 & 10.6 & 4.6 & 4.4 & 23.0 & -33.6 & 4.4 \\
\hline 20 & MS & 2018 & 12.2 & 50.7 & 11.9 & 4.7 & 5.0 & 31.1 & -30.9 & 3.2 \\
\hline 21 & MS & 2018 & 17.1 & 45.9 & 10.1 & 4.4 & 4.9 & 23.1 & 30.2 & 3.8 \\
\hline 22 & MS & 2018 & 15.6 & 47.0 & 10.3 & 4.3 & 4.4 & 20.5 & -29.1 & 3.9 \\
\hline 23 & MS & 2018 & 13.5 & 49.3 & 11.6 & 4.3 & 4.7 & 25.6 & 30.7 & 3.88 \\
\hline 24 & LA & 2019 & - & 30.0 & 7.2 & 4.1 & - & - & - & \\
\hline 27 & LA & 2019 & - & 39.9 & 7.6 & 5.2 & - & - & -37.2 & - \\
\hline 28 & LA & 2019 & - & 26.4 & 6.7 & 3.5 & - & - & - & - \\
\hline 29 & LA & 2019 & - & 24.4 & 6.2 & 3.8 & - & - & -36.3 & - \\
\hline 31 & LA & 2019 & - & 38.6 & 8.2 & 4.8 & - & - & - & - \\
\hline 35 & $\mathrm{AL}$ & 2019 & - & 31.0 & 7.4 & 3.9 & - & - & - & - \\
\hline 37 & $\mathrm{AL}$ & 2019 & - & 39.6 & 7.9 & 4.9 & - & - & -31.3 & - \\
\hline 40 & GA & 2019 & - & 47.5 & 8.9 & 5.2 & - & & -31.6 & - \\
\hline 41 & $\mathrm{AL}$ & 2019 & - & 28.9 & 6.6 & 4.2 & - & - & - & - \\
\hline 42 & GA & 2019 & - & 43.2 & 7.9 & 5.4 & - & - & - & \\
\hline 43 & $\mathrm{AL}$ & 2019 & - & 60.1 & 10.7 & 5.7 & - & - & - & - \\
\hline 44 & $\mathrm{AL}$ & 2019 & - & 31.6 & 7.0 & 4.3 & - & - & -34.6 & - \\
\hline 45 & $\mathrm{AL}$ & 2019 & - & 35.3 & 7.7 & 4.4 & - & - & - & \\
\hline 46 & AL & 2019 & - & 27.4 & 7.1 & 3.7 & - & - & -38.3 & - \\
\hline 47 & $\mathrm{AL}$ & 2019 & - & 40.5 & 8.5 & 4.6 & - & - & -35.8 & - \\
\hline 49 & GA & 2019 & - & 22.0 & 5.6 & 3.8 & - & - & - & - \\
\hline 50 & GA & 2019 & - & 32.1 & 7.4 & 4.2 & - & - & - & - \\
\hline 51 & GA & 2019 & - & 20.7 & 5.5 & 3.6 & - & - & - & - \\
\hline 52 & $\mathrm{AL}$ & 2019 & - & 22.7 & 5.7 & 3.8 & - & - & - & - \\
\hline 54 & $\mathrm{AL}$ & 2019 & - & 20.0 & 5.9 & 3.1 & - & - & - & - \\
\hline 56 & $\mathrm{AL}$ & 2019 & - & 17.5 & 5.3 & 3.1 & - & - & - & - \\
\hline 57 & $\mathrm{AL}$ & 2019 & - & 31.9 & 6.7 & 4.6 & - & - & -34.8 & - \\
\hline 58 & $\mathrm{AL}$ & 2019 & - & 25.3 & 6.2 & 3.9 & - & - & -36.0 & - \\
\hline 60 & GA & 2019 & - & 34.7 & 7.1 & 4.8 & - & - & -33.2 & - \\
\hline 61 & GA & 2019 & - & 27.2 & 7.0 & 3.4 & - & - & - & - \\
\hline 62 & GA & 2019 & - & 22.8 & 6.6 & 3.4 & - & - & - & - \\
\hline 64 & $\mathrm{AL}$ & 2019 & - & 21.8 & 6.1 & 3.3 & - & - & - & - \\
\hline 66 & $\mathrm{AL}$ & 2019 & - & 25.7 & 5.9 & 4.0 & - & - & - & - \\
\hline 67 & MS & 2019 & - & 46.1 & 9.5 & 4.8 & - & - & -33.1 & - \\
\hline 68 & MS & 2019 & - & 41.9 & 7.9 & 5.2 & - & - & - & - \\
\hline 70 & MS & 2019 & - & 24.2 & 5.5 & 3.8 & - & - & - & - \\
\hline 71 & MS & 2019 & - & 24.1 & 6.0 & 3.8 & - & - & - & - \\
\hline 72 & MS & 2019 & - & 28.7 & 7.1 & 4.0 & - & - & -35.0 & - \\
\hline 73 & MS & 2019 & - & 28.7 & 6.7 & 4.1 & - & - & - & - \\
\hline 75 & LA & 2019 & - & 44.9 & 8.3 & 5.3 & - & - & - & - \\
\hline
\end{tabular}

${ }^{\mathrm{z}}$ Values for populations that were phenotyped in multiple environments or years represent means across all environments tested.

${ }^{\mathrm{y}}$ Internode length was estimated by dividing the plant height by the number of nodes on the same stem.

${ }^{\mathrm{x}}$ Plant width is the average of the widest dimension and the width perpendicular to the widest dimension.

${ }^{\mathrm{w}}$ Winter damage was scored in the field in Minnesota. $1=$ maximum winter damage; $5=$ minimal winter damage.

${ }^{\mathrm{v}}$ Less than $50 \%$ of stem samples were killed at the coldest temperature tested. The temperature listed is the coldest temperature tested.

Dashes (-) indicate the population was not analyzed for the trait.

$\mathrm{AL}=$ Alabama; FL = Florida $; \mathrm{GA}=$ Georgia ID = identification; LA = Louisiana MS $=$ Mississippi; $\mathrm{TN}=\mathrm{Tennessee}$.

area affected by leaf spot (necrotic tissue and discoloration) was calculated for each leaf by dividing the number of pixels classified as each of the diseased categories by the number of nonbackground pixels and then multiplying by 100 . Population and cultivar means were assessed with an ANOVA and
Bonferroni-corrected for multiple comparisons. Each leaf was considered a replicate; therefore, there were 100 replicates for each population and 30 replicates for each cultivar.

Several representative infected leaves were submitted to the University of Minnesota Plant Disease Clinic to verify the identity of the pathogen. The pathogen was determined to be Xanthomonas campestris, which was consistent with the expectation. No additional pathogens were detected.

Cold hardiness. The older seedling cohort was tested for cold hardiness in January 2019, with a controlled freezing test. These 
A

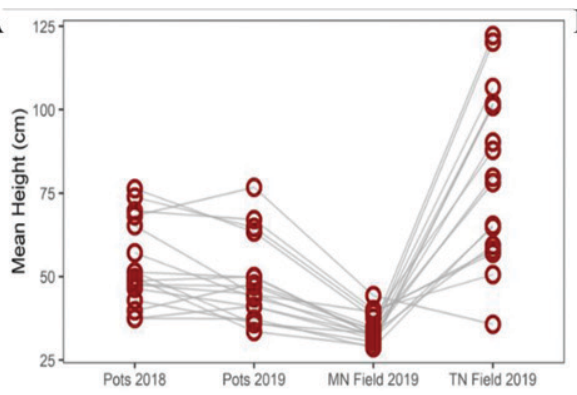

B

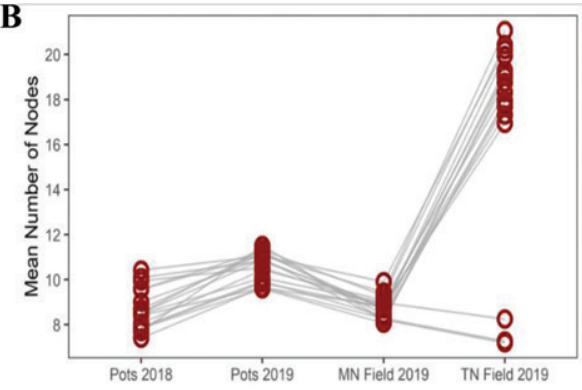

D

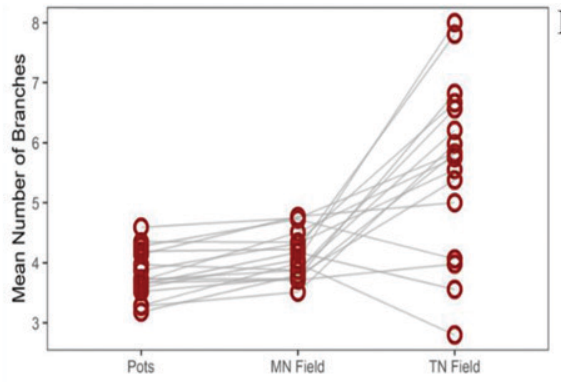

E

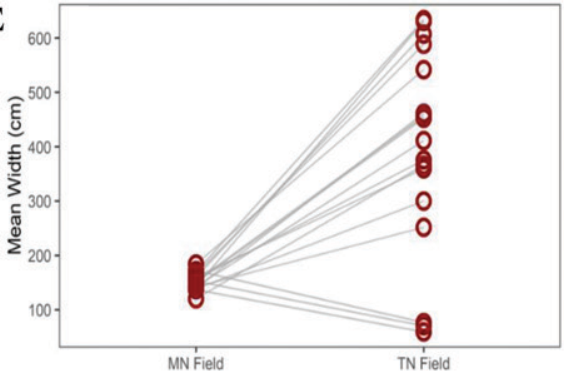

C

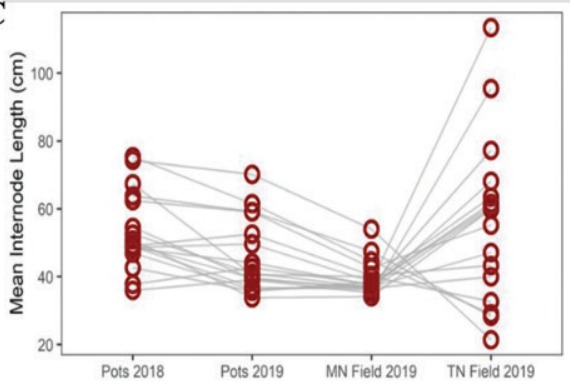

Fig. 3. Effects of interaction of population $\times$ environment on five Hydrangea quercifolia plant architecture traits. Each circle represents the mean of a wild seedling population for each environment and year combination. Circles representing the same population are connected with a line.

methods were based on those described previously for controlled hardiness screening (McNamara et al., 2002; McNamara and Hokanson, 2010). The container-grown seedlings were allowed to acclimate under ambient conditions until mid-November, when they were moved into a minimally heated greenhouse structure maintained at a minimum temperature of $-9.5^{\circ} \mathrm{C}$ to avoid cold damage before sampling. The seedlings were sampled on four dates over the course of 2 weeks $(6,10,13$, and 17 Jan.) in a completely randomized experimental design. Each sample operation consisted of harvesting and preparing stem samples on the first day and freezing the stems the following day. On the first day of each sampling date, stems from seedlings of each population to be tested that day were taken to the laboratory and cut into $3.5-\mathrm{cm}$ sections, color-coded, and then randomly assigned to one of six temperature treatments or a nonfrozen control. Stem sections from each population at each temperature treatment were placed into bags with moist paper towels (three replicate bags per temperature per sample date). The bags were placed in a ScienTemp freezer (ScienTemp Corporation, Adrian, MI) controlled by a Watlow series 942 temperature controller (Watlow, St. Louis, MO). Each bag contained stem sections from all populations, with a total of 8 to 12 stem samples per population per test temperature. A thermocouple was inserted into the pith of at least one stem section per temperature treatment to monitor the stem temperature throughout the experiment. Temperatures were slowly decreased to the first test temperature $\left(-10^{\circ} \mathrm{C}\right)$ overnight to allow stem temperatures to equilibrate. The following day, temperatures were decreased at a rate of $3{ }^{\circ} \mathrm{C}$ per hour, and three replicate bags for each treatment were removed from the freezer at increments of -5 to $-35^{\circ} \mathrm{C}$. Samples were removed from the freezer when each test temperature was reached. Stem sections were slowly thawed at $3{ }^{\circ} \mathrm{C}$ overnight and incubated at room temperature for 1 week to allow damage symptoms to appear. Stem sections were evaluated for cold damage by slicing the stem longitudinally with a scalpel and rating stems as live or dead by observing the damage (oxidative browning of vascular tissue) under a dissecting microscope $(12 \times$ magnification). Most stems were unambiguously dead or alive; however, some stems were intermediate. In that case, stems were classified according to having more than or less than $50 \%$ damage. Cold hardiness was determined as the mean lethal temperature $\left(\mathrm{LT}_{50}\right)$ and calculated for each population using a binomial logit model to interpolate the temperature at which $50 \%$ of the stems would have died (Suojala and Lindén 1997). The binomial logit model was implemented in the $\mathrm{R}$ packages MASS (v7.3-50) and stats (v3.5.1).

The experiment was repeated during late Fall 2019 thru early Spring 2020, with a subset of populations from both the younger and older seedling cohorts as well as a selection of cultivars. During this experiment, plants were tested once per month from October to April to characterize the timing of fall acclimation and spring deacclimation in addition to midwinter hardiness using the methods described. The tested temperatures (and interval between test temperatures) were varied each month to exceed the expected range of $\mathrm{LT}_{50}$ values (Table 2). During

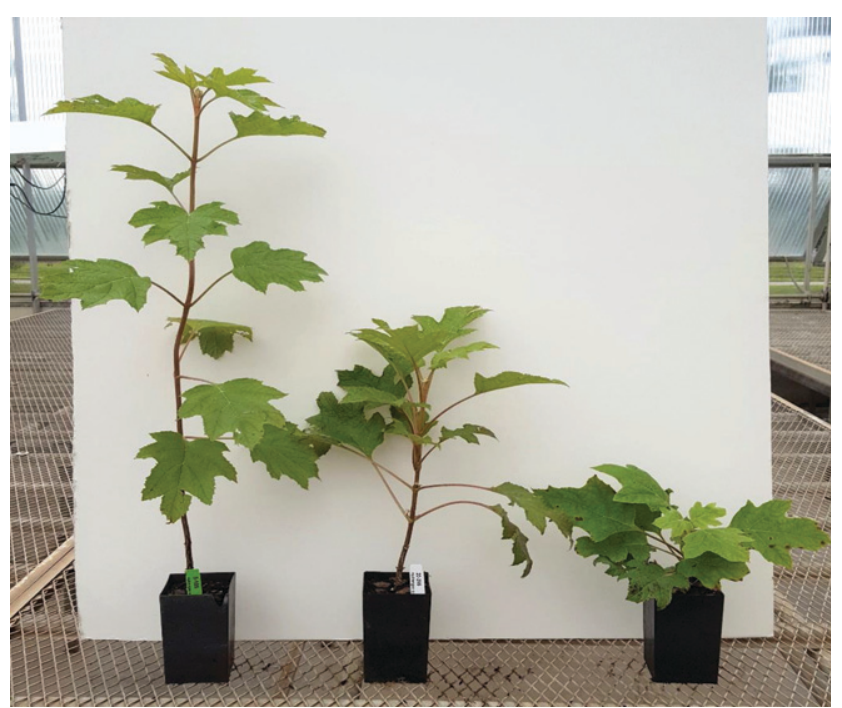

Fig. 4. Photograph showing representative variation in seedling height and internode length for wildcollected Hydrangea quercifolia. 

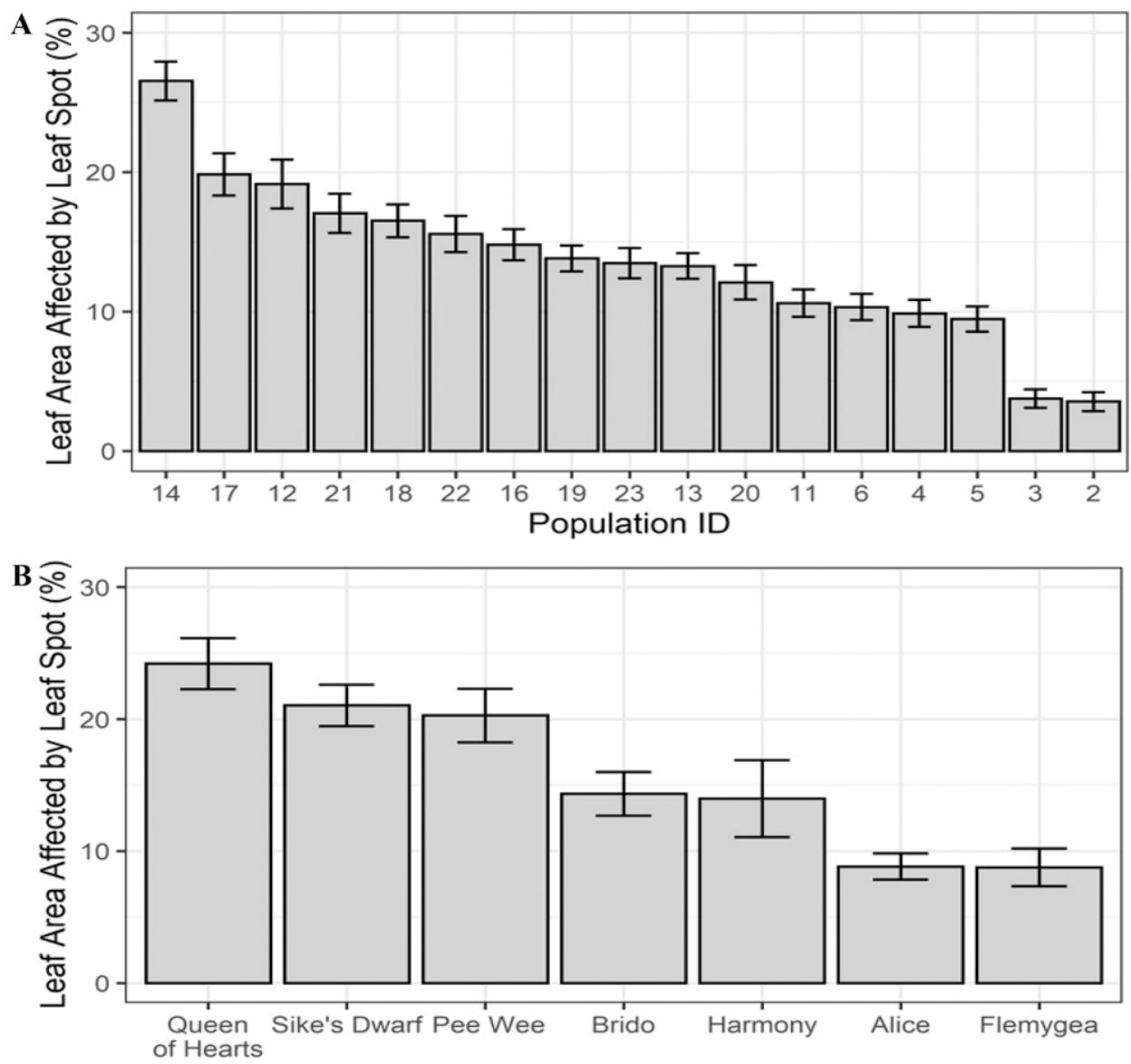

Fig. 5. Bar plots indicating the mean percent leaf area affected by leaf spot (Xanthomonas campestris) for Hydrangea quercifolia that were exposed to natural inoculum. Wild-collected seedling populations (A) and cultivars (B). Error bars indicate the SEM.

each month, the sample from a population or cultivar comprised one random stem collected from multiple individual plants; therefore, each plant was resampled every month. Cultivars were tested with four to six stem samples per cultivar per temperature per month while the populations were tested with the same sample sizes as those during January 2019.

In May 2020, the seedlings growing in the field in Minnesota (older cohort) were

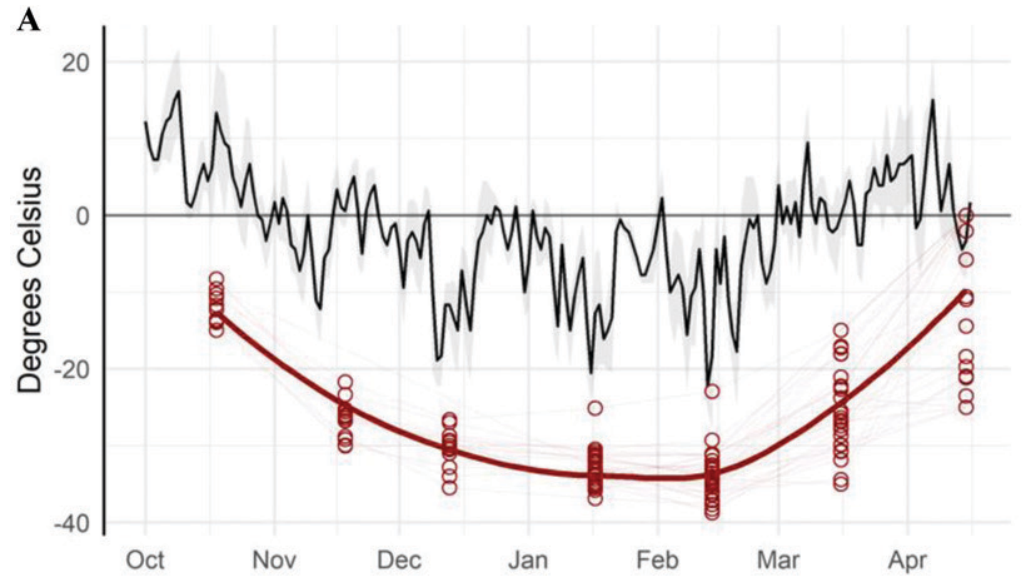

evaluated for winter damage using a scale from 1 to 5 . The damage scores were as follows: $1=81 \%$ to $100 \%$ of the aboveground tissue received winter damage; $2=61 \%$ to $80 \%$ damage; $3=41 \%$ to $60 \%$ damage; $4=$ $21 \%$ to $40 \%$ damage; and $5=0 \%$ to $20 \%$ damage. These field ratings were analyzed among populations with an ANOVA and compared with the laboratory-based $\mathrm{LT}_{50}$ values using the Pearson correlation.

\section{Results}

Plant architecture. Populations varied significantly during both years and in all environments tested for all plant architecture traits $(P<0.001)$ (Table 3, Figs. 3 and 4). When averaged across growing environments, plant height was inversely correlated with the collection site latitude. The association was slightly, although not significantly

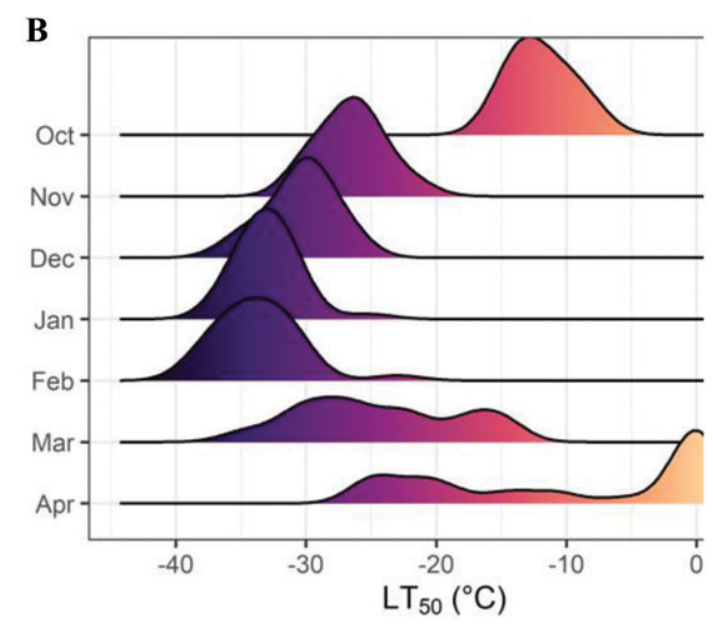

Fig. 6. Cold hardiness of Hydrangea quercifolia measured with a controlled freezing assay measured as the lowest temperature at which $50 \%$ of the samples survive [mean lethal temperature $\left(\mathrm{LT}_{50}\right)$ ]. (A) $\mathrm{LT}_{50}$ and outdoor temperature in Winter 2019 to 2020 . The black line indicates mean daily temperature in Chanhassen, MN. The grey ribbon indicates daily high and low temperatures. Circles represent $\mathrm{LT}_{50}$ for each population and cultivar tested each month. (B) Ridgeline plot displays the density distribution of the estimated $\mathrm{LT}_{50}$ each month, with color representing $\mathrm{LT}_{50}$. 
$(P=0.82)$, stronger in the older cohort $(\mathrm{r}=$ $-0.68 ; P=0.003)$ than in the younger cohort $(\mathrm{r}=-0.64 ; P<0.001)$. The ANOVA revealed that plant architecture varied significantly by environment and year, with the plants generally being the tallest and widest with the longest internodes when grown in Tennessee $(P<0.001 ; \mathrm{F}=755.2)$. Among the Minnesota-grown plants, the seedlings grew taller in containers than in the field.

Leaf spot tolerance. The total percent leaf area affected by leaf spot ranged from $3.5 \%$ in population 2 (Florida) to $26.5 \%$ in population 14 (Tennessee), and significant differences were detected among populations $(P<0.001$; $\mathrm{F}=17.6$ ) (Table 3, Fig. 5A). Among the cultivars, the total percent leaf area affected ranged from $8.8 \%$ for 'Flemygea' to $24.2 \%$ for 'Queen of Hearts' (Table 1, Fig. 5B). On average, cultivars had a higher leaf area affected than the wild seedlings (two-sample $t$ test $P=$ 0.006 ), although there was more variation among the wild seedling populations.

The percent leaf area affected by necrotic tissue and discoloration were correlated $(\mathrm{r}=0.44$; $P<0.001$ ) and leaves typically had a greater area affected by necrosis than discoloration. However, there were two exceptions to this: 'Queen of Hearts' had a greater leaf area affected by discoloration and 'Alice' had nearly equal leaf areas affected by discoloration and necrosis. The total percent leaf area affected was positively correlated with latitude $(\mathrm{r}=0.70 ; P=0.002)$, with the populations originating in Florida having the lowest disease severity.

Cold hardiness. For Minnesota-grown plants tested during January 2019, significant differences were found for the estimated $\mathrm{LT}_{50}$ among populations. The $\mathrm{LT}_{50}$ values for the populations ranged from $-27.1^{\circ} \mathrm{C}$ (population 4, Florida) to $-33.2^{\circ} \mathrm{C}$ (population 19, Mississippi). Among the wild populations, $\mathrm{LT}_{50}$ was inversely correlated with latitude ( $\mathrm{r}=-0.71 ; P=0.003)$; the northern populations were generally more cold-hardy than the southern populations. 'Ruby Slippers', the only cultivar tested during January 2019, had an estimated $\mathrm{LT}_{50}$ of $-35^{\circ} \mathrm{C}$.

During Winter 2019 to 2020, significant differences were detected among cultivars and wild populations during each month (Table 1). Additionally, significant differences were detected among months of the winter $(P<$ $0.001 ; \mathrm{F}=74.4)$, with maximum cold hardiness achieved in December, January, or February, depending on the population (Fig. 6A). The overall mean $\mathrm{LT}_{50}$ was the lowest (most cold hardy) in February, with an $\mathrm{LT}_{50}$ of $-33.7^{\circ} \mathrm{C}$. More variation was found among populations and cultivars during early and late winter than during midwinter, with the most variation during deacclimation in March and April (Fig. 6B). With the broader sampling of wild populations compared with January 2019 , the inverse correlation between January $\mathrm{LT}_{50}$ and latitude remained significant, but the association was weaker $(\mathrm{r}=-0.58 ; P=0.006)$.

Population 4 (Florida) was consistently the least hardy population, except in October. No population was consistently the most coldhardy throughout winter. However, there was

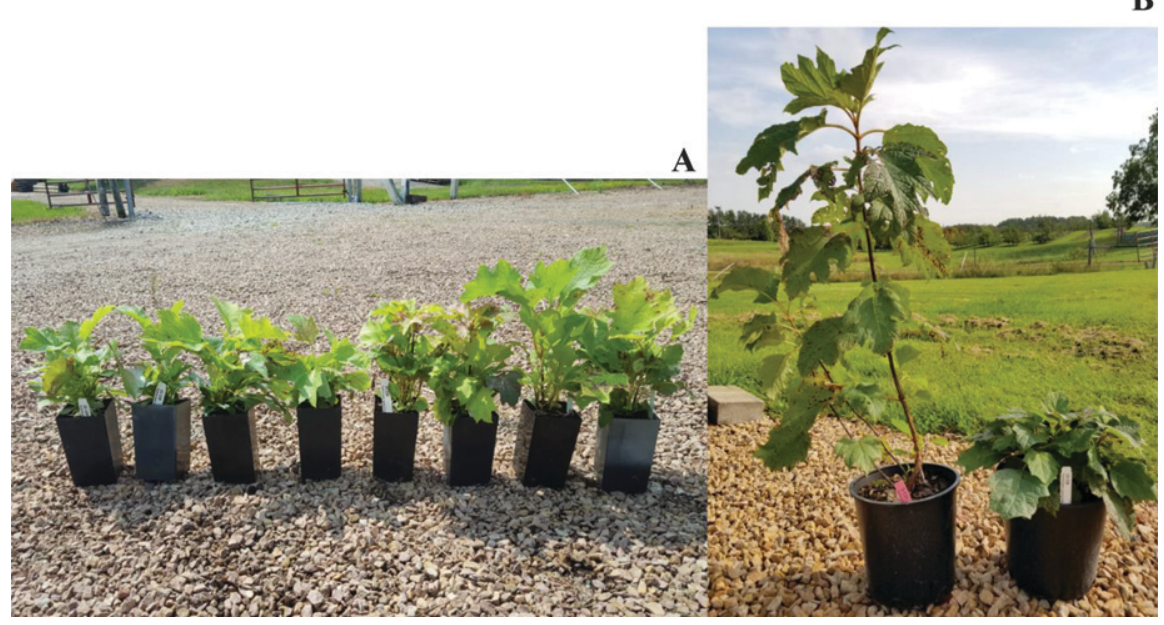

Fig. 7. Photographs showing putative mutants with increased basal branching in wild-collected Hydrangea quercifolia seedling populations. (A) All eight putative mutants from population 22 (Mississippi) in 2018. (B) Comparison of one putative mutant next to a typical seedling from population 3 (Florida). considerable variation in deacclimation timing, with two populations (populations 9 and 58, Alabama) maintaining extreme cold hardiness into March and several populations surviving the lowest temperature tested $\left(-25^{\circ} \mathrm{C}\right)$ in April (populations 10, 37, and 47, Alabama). 'Sike's Dwarf' was the most coldhardy cultivar throughout the middle of winter, but it had the fastest rate of deacclimation between March and April. 'Sike's Dwarf' no longer tolerated freezing in April after an increase of $28.7^{\circ} \mathrm{C}$ in $\mathrm{LT}_{50}$. In contrast, 'Ruby Slippers' had moderate cold hardiness in midwinter, but it maintained a high level of cold hardiness into March and April. 'Flemygea' was consistently among the least cold-hardy cultivars throughout winter.

Significant differences were found for winter damage scores recorded in the field among populations $(P<0.001 ; \mathrm{F}=87.3)$. The population mean winter damage scores ranged from 2.5 (population 2, Florida) to 5.0 (population 13, Tennessee). Field winter damage was significantly correlated with the latitude of the collection location $(\mathrm{r}=-0.91$; $P<0.001)$ and laboratory-based $\mathrm{LT}_{50}(\mathrm{r}=$ $-0.63 ; P=0.013)$.

\section{Discussion}

Populations of $H$. quercifolia varied significantly for all traits measured. Many of these traits varied geographically and correlated with the latitude of seed origin. The traits also varied significantly among growing environments.

Although plant architecture was significantly different in each of the growing environments tested, the largest differences were between Minnesota and Tennessee (Fig. 3). This difference is likely explained by the longer growing season in Tennessee compared with that in Minnesota. The differences in growth within Minnesota (2018 in pots, 2019 in pots, and 2019 in the field) could be attributable to the closer spacing of the containerized plants during their first year of growth compared with that during the second year, which induced a competitive response for light and resulted in shoot elongation. Even within 2019 in Minnesota, the plants grew differently in containers than in the field; the plants were generally more compact and more highly branched in the field, where they were more widely spaced and experienced less competition for light. These results

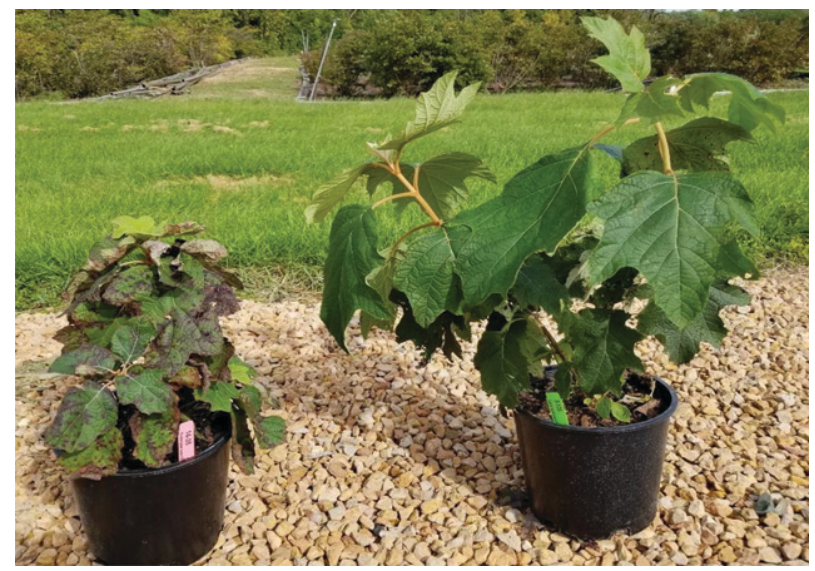

Fig. 8. Photograph of Hydrangea quercifolia seedlings with contrasting leaf spot severity. A representative seedling from population 14 (Tennessee) (left) and a representative from population 5 (Florida) (right). 
indicate that plant architecture traits of oakleaf hydrangea should be evaluated in multiple environments (or the environment most relevant to the breeding objectives) to ensure that selections will have the desired phenotype in the target environment.

For other ornamental plants, components of plant architecture have been shown to have a genetic basis. For example, Crespel et al. (2012) determined that two subspecies of $H$. aspera have qualitatively different plant architectures. Additionally, several studies have identified the components of plant architecture of rose (Crespel et al., 2013, 2014). Li-Marchetti et al. (2017) identified between three and seven quantitative trait loci (QTL) for the traits analyzed. Similar studies of Lagerstroemia have quantified genotype $\times$ environment interactions (Pounders et al., 2010) and QTL linked to compactness (Ye et al., 2016), for which three QTL were also identified. As in the current study of $H$. quercifolia, the plant architecture of both of these species was found to have a genetic component (variation among populations) despite the significant effect of environmental factors. Furthermore, as expected for quantitative traits such as plant architecture, it is likely that several loci control each of these plant architecture traits.

Three populations (populations 12, 13, and 14, Tennessee) were more consistent across environments than the others for the plant architecture traits. Interestingly, these populations also contained some of the most compact plants. Variability across environments was correlated with the population mean height when variability increased with height $(\mathrm{r}=$ $0.81 ; P<0.001)$. Stability in various environments for compactness would be an important production trait because the phenotype would be relatively predictable regardless of the growing environment. Therefore, it may be desirable to use these populations for breeding as a source of stable compact plant architecture.

The correlation of plant height with latitude is congruent with the variation that has been documented among species worldwide (Moles et al., 2009). For H. quercifolia, the clinal variation in plant height mainly occurred because the plants from Florida were the tallest averaged across years and environments. Because the younger seedling cohort did not include populations from Florida (both the most extreme phenotype and the lowest latitude), the trend was weaker but still significant.

Potential novel sources of compactness were identified from at least two sources. Plants from northern latitudes (especially in the northeastern portion of the range) tended to be shorter, with smaller internodes. Although the number of branches did not follow a clear geographical pattern, one family from population 22 (Mississippi) had eight seedlings that were highly branched, with very small internodes (mean number of branches in the putatively mutant seedlings $=8.1$ ) (Fig. 7A). This may represent a source of qualitative variation considering the discrete categories to which the seedlings in this family could be assigned (Fig. 7B). Both of these sources could be used for breeding novel compact oakleaf hydrangea varieties. For example, the putative mutants could be crossed with large plants from Florida to introgress leaf spot tolerance while still potentially recovering highly compact progeny.

A difference in leaf spot severity more than 7-fold was detected among the plants studied. Wild $H$. quercifolia populations in Florida, especially populations 2 and 3, could serve as sources of Xanthomonas tolerance for breeding (Fig. 8). Populations in Florida encounter substantially different environmental conditions than the remainder of the native range of the species, including higher precipitation and higher temperatures. These high moisture conditions likely favor growth of the causal pathogen (Dixon et al., 2002); therefore, wild populations could have been subjected to stronger disease pressure and developed greater tolerance. Although no plants were found to be entirely resistant, the leaf with the lowest disease severity was from a population 3 (Florida) seedling with $0.03 \%$ total leaf area affected. It is possible that a leaf such as this may have encountered a lower inoculum level than others by chance. However, at the population level, it is likely that the detected differences represent true tolerance because the populations were grown in the same nursery and had equivalent disease pressure. Two cultivars can also be used as sources of moderate leaf spot tolerance. 'Alice' and 'Flemygea' are the only two cultivars tested with less than $10 \%$ leaf area affected. Additional testing with controlled inoculations could potentially identify individuals within each of the Florida populations with higher leaf spot tolerance than either 'Alice' or 'Flemygea'.

Tolerance to leaf spot caused by $X$. campestris has been identified in other species by

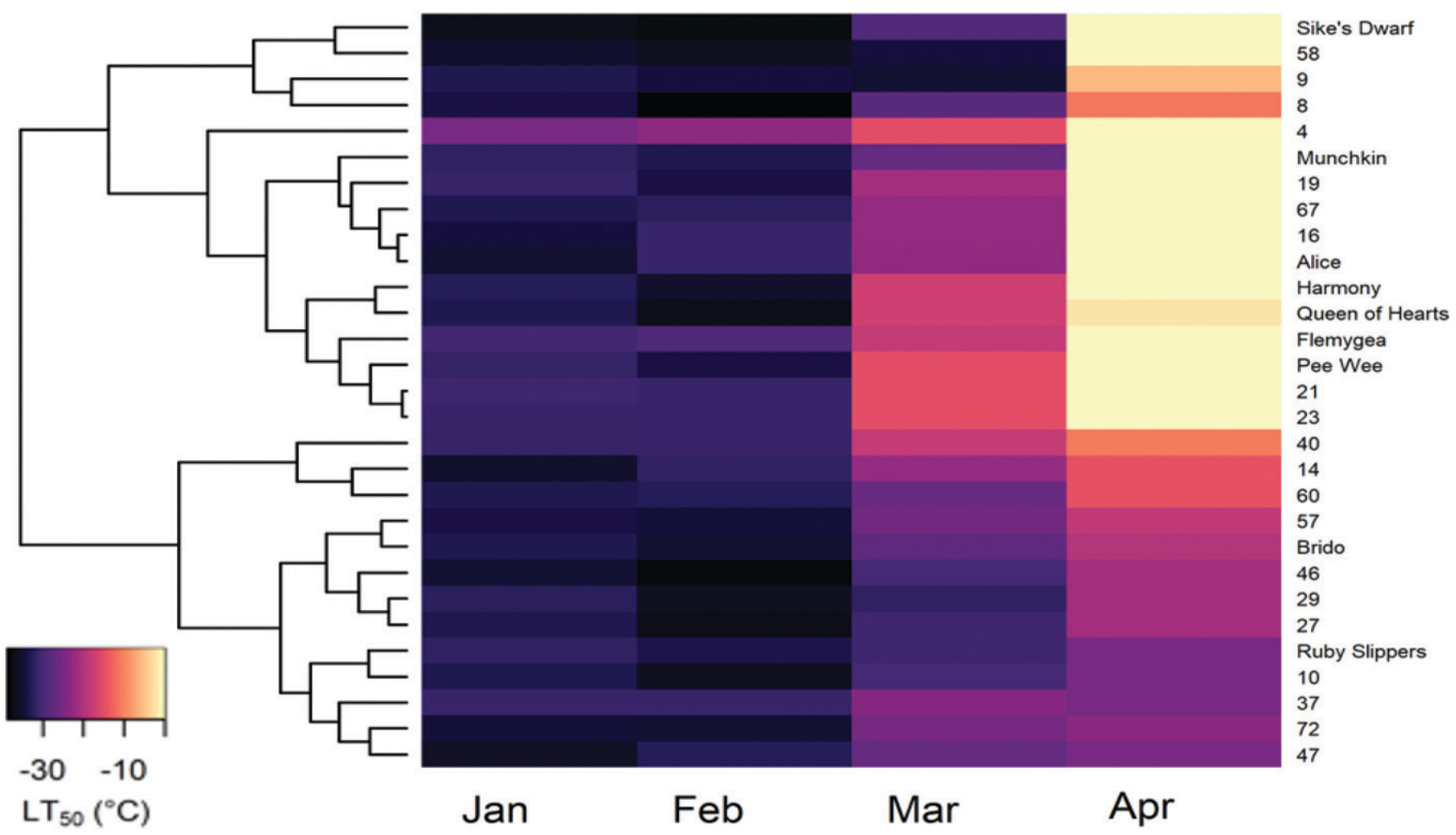

Fig. 9. Heatmap depicting $\mathrm{LT}_{50}$ for each Hydrangea quercifolia population and cultivar during deacclimation. Dark colors represent lower $\mathrm{LT}_{50}$ and lighter colors represent higher mean lethal temperature $\left(\mathrm{LT}_{50}\right)$. Hierarchical clustering separates the populations and cultivars into two groups: one that loses cold hardiness early in the winter and another that maintains cold hardiness into April. 
screening diverse germplasm. Leaf spot tolerance has been identified in strawberry (Maas et al., 2000; Roach et al., 2016), sesame (Naqvi et al., 2012), and lettuce (Hayes et al., 2014). Tolerance to $X$. campestris has been shown to have a very high heritability in mulberry (Banerjee et al., 2012), which suggests that selecting for leaf spot tolerance should lead to efficient genetic gain.

Interestingly, all three compact cultivars included in this study ('Sike's Dwarf', 'Pee Wee', and 'Queen of Hearts') had the highest disease severity of the tested cultivars. Similarly, wild seedlings from populations with the most compact habit (population 14, Tennessee) also had the highest disease severity. One possible explanation is unfavorable linkage between genetic loci controlling both traits. Another possible explanation is a pleiotropic effect of plant height and/or compactness on leaf spot severity by making the leaves more accessible to inoculum that spreads upward through a plant from fallen leaves. In this case, the increased canopy density on compact plants would create a favorable microclimate for the pathogen around the plant with increased humidity and decreased air flow, as well as a shorter distance for splash dispersal among leaves. A third possible explanation is that the cultivars were selected from a population exhibiting lower disease tolerance. However, the germplasm sources from which 'Sike's Dwarf' and 'Pee Wee' were selected are unknown.

Cold hardiness varied as a latitudinal cline, with the northern populations being more coldhardy. However, like height, the populations from Florida had a greater contribution to this pattern because they were consistently the least cold hardy. Despite being from similar latitudes as the populations from Louisiana and southern Mississippi, the Florida populations were substantially less cold hardy. A correlation between cold hardiness and latitude has been found for several other woody species, such as Pinus sylvestris L. (Hurme et al., 1997), $P$. greggii Engelm. (Aldrete et al., 2008), and Acer platanoides L. (Pagter et al., 2010); therefore, it appears to be a general phenomenon for woody plants. Pinus greggii is particularly interesting because it is also from North America and exhibits a similar phenomenon of withstanding temperatures colder than would be expected based on its native range. The northernmost population tested by Aldrete et al. (2008) was from $\approx 25^{\circ} \mathrm{N}$ (northern Mexico) and had an $\mathrm{LT}_{50}$ of $-18^{\circ} \mathrm{C}$. This is consistent with the observation during the present study that the southernmost $H$. quercifolia population was from $\approx 30{ }^{\circ} \mathrm{N}$, where average minimum temperatures historically range from -12.2 to $-9.4^{\circ} \mathrm{C}$ (USDA Plant Hardiness Zone Map, 2012) and had an $\mathrm{LT}_{50}$ of $-27^{\circ} \mathrm{C}$. Although this excessive capacity to withstand cold could be speculated to be caused by glacial refugia, minimum winter temperatures vary by latitude $(\mathrm{r}=-0.98 ; P<0.001)$; therefore, they likely have a selective influence on cold hardiness.

The cultivar that exhibited the lowest $\mathrm{LT}_{50}$ was 'Sike's Dwarf' in February $\left(-37.7^{\circ} \mathrm{C}\right)$.
Among the wild seedlings, population 8 (Alabama) had the lowest $\mathrm{LT}_{50}$ in February (mean, $-38.7^{\circ} \mathrm{C}$ ), although population 46 (Alabama) was very similar (mean, $-38.3^{\circ} \mathrm{C}$ ). These $\mathrm{LT}_{50}$ values were lower than expected for the species based on a previous study of 'Alison' and 'Alice' (Dirr et al., 1993). In that study, 'Alice' was found to be most hardy in December $\left(\mathrm{LT}_{50}=-27^{\circ} \mathrm{C}\right)$; however, in this study, 'Alice' was most cold hardy in January $\left(\mathrm{LT}_{50}=-35^{\circ} \mathrm{C}\right)$. The previous study was performed in Georgia, which likely reduced the level of acclimation achieved (McNamara et al., 2002). During that study, the authors assessed the cold hardiness of several species of woody plants acclimated in Georgia compared with Minnesota and found that the same genotype acclimated in Minnesota achieved a greater degree of cold hardiness for all species tested. Although population $\mathrm{LT}_{50}$ estimates were different in Jan. 2019 and Jan. 2020 in the present study, the two samples were not significantly different $(P=0.64)$, indicating that under the controlled winter conditions used during this experiment, the between-year variation was minimal. These annual differences

Table 4. Locations of each Hydrangea quercifolia population and corresponding National Plant Germplasm System accession number.

\begin{tabular}{|c|c|c|c|c|c|}
\hline Pop. ID & State & Latitude & Longitude & Site name & $\begin{array}{c}\text { NPGS accession } \\
\text { number }\end{array}$ \\
\hline 2 & $\overline{\mathrm{FL}}$ & 30.56973 & -84.9402 & Torreya State Park & NA 86149 \\
\hline 3 & FL & 30.62958 & -84.896 & I-10 Rest Stop & NA 86150 \\
\hline 4 & FL & 30.69707 & -84.8491 & Angus Gholson Nature Park & NA 86151 \\
\hline 5 & GA & 30.71394 & -84.8515 & Jim Woodruff Cliff & - \\
\hline 6 & FL & 30.8114 & -85.2295 & Florida Caverns State Park & NA 86152 \\
\hline 8 & $\mathrm{AL}$ & 31.90617 & -87.38187 & Gullet's Bluff & NA 86154 \\
\hline 9 & $\mathrm{AL}$ & 33.35335 & -86.7045 & Oak Mountain State Park & NA 86155 \\
\hline 10 & $\mathrm{AL}$ & 34.09298 & -87.6116 & Natural Bridge & NA 86156 \\
\hline 11 & $\mathrm{TN}$ & 35.03504 & -88.7289 & Big Hill Pond State Park & NA 86157 \\
\hline 12 & $\mathrm{TN}$ & 35.0513 & -88.2367 & Pickwick Landing State Park & NA 86158 \\
\hline 13 & $\mathrm{TN}$ & 35.46251 & -87.2685 & Stillhouse Hollow Falls & NA 86159 \\
\hline 14 & $\mathrm{TN}$ & 35.80094 & -85.623 & Rock Island State Park & NA 86160 \\
\hline 16 & MS & 34.25801 & -88.9006 & Trace State Park & NA 86161 \\
\hline 17 & MS & 34.60074 & -88.1853 & Tishomingo State Park & NA 86162 \\
\hline 18 & MS & 33.61316 & -89.4099 & The Old Cove & NA 86163 \\
\hline 19 & MS & 33.41539 & -89.264 & Jeff Busby Park & NA 86164 \\
\hline 20 & MS & 31.18147 & -89.0506 & DeSoto National Forest & NA 86165 \\
\hline 21 & MS & 31.74519 & -88.523 & Old US 84 & NA 86166 \\
\hline 22 & MS & 31.99717 & -89.3564 & Cat's Den Preserve & NA 86167 \\
\hline 23 & MS & 32.3259 & -90.1561 & LeFleur's Bluff State Park & NA 86168 \\
\hline 24 & MS & 31.42324 & -90.9846 & Clear Springs & NA 86169 \\
\hline 27 & LA & 30.92754 & -91.5287 & Tunica Hills & NA 86171 \\
\hline 28 & LA & 31.80523 & -91.7576 & Sicily Island & NA 86172 \\
\hline 29 & LA & 31.21508 & -92.6711 & Kisatchie National Forest & NA 86173 \\
\hline 31 & LA & 30.8235 & -91.2657 & Marry Ann Brown Nature Preserve & NA 86174 \\
\hline 35 & $\mathrm{AL}$ & 31.51681 & -86.5307 & Hwy 23 & NA 86176 \\
\hline 37 & $\mathrm{AL}$ & 31.18501 & -86.6953 & Conecuh River & NA 86177 \\
\hline 40 & GA & 31.89825 & -85.1089 & River Bluff Park & NA 86179 \\
\hline 41 & AL & 32.06199 & -85.8993 & High Ridge & NA 86180 \\
\hline 42 & GA & 31.30734 & -85.0817 & Coheelee Creek & NA 86181 \\
\hline 43 & $\mathrm{AL}$ & 31.47532 & -85.6284 & Dale County Lake & NA 86182 \\
\hline 44 & $\mathrm{AL}$ & 32.88895 & -87.4279 & Talladega National Forest & NA 86183 \\
\hline 45 & $\mathrm{AL}$ & 32.39916 & -86.7821 & Bob Woodruff Park & NA 86184 \\
\hline 46 & $\mathrm{AL}$ & 32.5959 & -85.8803 & Coon Creek Forever Wild Preserve & NA 86185 \\
\hline 47 & $\mathrm{AL}$ & 32.54893 & -85.4778 & Chewacla State Park & NA 86186 \\
\hline 49 & GA & 32.8409 & -84.8392 & Franklin D. Roosevelt State Park & NA 86187 \\
\hline 50 & GA & 32.96549 & -84.4978 & Camp Thunder & NA 86188 \\
\hline 51 & GA & 33.79689 & -84.3175 & Lullwater Preserve & NA 86189 \\
\hline 52 & $\mathrm{AL}$ & 34.47173 & -86.0501 & Buck's Pocket State Park & NA 86190 \\
\hline 54 & AL & 34.4167 & -86.5965 & Hugh's Spring & NA 86192 \\
\hline 56 & AL & 33.87496 & -86.8651 & Rickwood Caverns State Park & NA 86194 \\
\hline 57 & $\mathrm{AL}$ & 33.28056 & -87.4068 & Rocky Branch Public Use Area & NA 86195 \\
\hline 58 & AL & 34.28716 & -85.6843 & Little River Canyon & NA 86196 \\
\hline 60 & GA & 34.43213 & -85.3365 & James H. Floyd State Park & NA 86197 \\
\hline 61 & GA & 34.87422 & -84.7192 & Mill Creek & NA 86198 \\
\hline 62 & GA & 34.84345 & -85.4789 & Cloudland Canyon State Park & NA 86199 \\
\hline 64 & AL & 33.46074 & -85.8182 & Cheaha Mtn. & NA 86201 \\
\hline 66 & AL & 33.83529 & -85.6372 & Dugger Mtn. & NA 86203 \\
\hline 67 & MS & 31.32607 & -89.9449 & Red Bluff & NA 86204 \\
\hline 68 & MS & 32.35323 & -90.7748 & I-20 at Vicksburg & NA 86205 \\
\hline 70 & MS & 34.37356 & -89.3521 & Puskus Lake & NA 86207 \\
\hline 71 & MS & 34.51675 & -88.547 & Hwy 366 & NA 86208 \\
\hline 72 & MS & 33.22734 & -89.0906 & Tombigbee National Forest & NA 86209 \\
\hline 73 & MS & 33.84466 & -89.6729 & Carver's Point State Park & NA 86210 \\
\hline 75 & LA & 32.08062 & -92.0592 & Charles Allen Nature Preserve & NA 86211 \\
\hline
\end{tabular}

$\mathrm{AL}=$ Alabama; $\mathrm{FL}=$ Florida $; \mathrm{GA}=$ Georgia ID $=$ identification $; \mathrm{LA}=$ Louisiana; $\mathrm{MS}=$ Mississippi; $\mathrm{NPGS}=$ National Plant Germplasm System; TN = Tennessee; $-=$ no seed was available for deposit in the NPGS. 
would likely be larger under natural acclimation conditions in field-grown plants (Pagter et al., 2011b). The average $\mathrm{LT}_{50}$ among all cultivars and populations was lowest in February $\left(\mathrm{LT}_{50}=-33.7^{\circ} \mathrm{C}\right)$, and was lower than previous estimates for the hardiest $H$. macrophylla cultivars $\left(\mathrm{LT}_{50}=-24^{\circ} \mathrm{C}\right.$ ) (Adkins et al., 2003).

Cold hardiness determined by laboratorybased freezer assays had been demonstrated to correlate well with field survival for Weigela florida Bunge cultivars $(\mathrm{r}=0.80)$ (McNamara and Hokanson 2010), and the results of the current study corroborate the validity of such cold hardiness estimates. However, considering the imperfect correlation in both studies, field-based estimates are preferable to laboratory-based estimates when making planting recommendations or decisions. The slightly weaker correlation between laboratory-based $\mathrm{LT}_{50}$ and winter damage recorded in the field from this study compared with those of McNamara and Hokanson (2010) is likely attributable to the use of seedling population means rather than cultivar means.

During Winter 2019 to 2020, the timing of acclimation and deacclimation varied among populations and cultivars. Greater variation was detected in deacclimation than in acclimation or midwinter hardiness. During late Winter 2020, the populations and cultivars split into one group that deacclimated rapidly and one group that maintained cold hardiness through April (two-sample $t$ test, $P<0.001$ in April and $P=0.04$ in March) (Fig. 9). Therefore, midwinter cold hardiness does not seem to be the primary limiting factor for winter survival; instead, deacclimation timing and cold hardiness in late winter are the primary limiting factors for winter survival. Additionally, because oakleaf hydrangea flowers on second-year wood and hydrangea flower buds are less hardy than stems (Pagter and Williams 2011), the survival of stems does not necessarily indicate that the plants will flower during the subsequent summer. Additional work to identify genotypes with exceptional flower bud hardiness are required.

Considering cold hardiness and bacterial leaf spot tolerance, for which both cultivars and wild germplasm were evaluated, variations in wild populations exceeded those of the cultivars. Regarding the traits of lower leaf spot severity or lower $\mathrm{LT}_{50}$, wild oakleaf hydrangea cannot be said to be generally superior to the cultivars; however, certain populations did have either lower leaf spot severity or lower $\mathrm{LT}_{50}$. Therefore, selectively including wild oakleaf hydrangea germplasm in a breeding program has the potential to provide novel variation that exceeds that available in the commercial germplasm. For example, crossing disease-resistant individuals from one of the Florida populations with compact and cold hardy individuals from the northeastern portion of the range of the species could result in compact progeny with cold hardiness and leaf spot tolerance. The seed collected during this study has been deposited to the USDA National Plant Germplasm System to be made available to breeders and researchers via the Germplasm Resource Information Network (Table 4).

\section{Literature Cited}

Adkins, J.A., M.A. Dirr, and O.M. Lindstrom. 2003. Cold hardiness estimates for ten Hydrangea taxa. Acta Hort. 618:163-168.

Aldrete, A., J.G. Mexal, and K.E. Burr. 2008 Seedling cold hardiness, bud set, and bud break in nine provenances of Pinus greggii Engelm. For. Ecol. Mgt. 255:3672-3676, doi: 10.1016/j. foreco.2008.02.054.

Arora, R. and L.J. Rowland. 2011. Physiological research on winter-hardiness: Deacclimation resistance, reacclimation ability, photoprotection strategies, and a cold acclimation protocol design. HortScience 46:1070-1078.

Banerjee, R., N.K. Das, S.G. Doss, A.K. Saha, A.K. Bajpai, and B.B. Bindroo. 2012. Narrow sense heritability estimates of bacterial leaf spot resistance in pseudo $\mathrm{F}_{2}\left(\mathrm{~F}_{1}\right)$ population of mulberry (Morus spp.). Eur. J. Plant Pathol. 2:537-544, doi: 10.1007/s10658-011-9894-z.

Crespel, L., C. Le Bras, D. Relion, and P. Morel. 2014. Genotype $\times$ year interaction and broadsense heritability of architectural characteristics in rose bush. Plant Breed. 133:412-418, doi: 10.1111/pbr.12157.

Crespel, L., P. Morel, and G. Galopin. 2012. Architectural and genetic characterization of Hydrangea aspera subsp. aspera Kawakami group, $H$. aspera subsp. sargentiana and their hybrids. Euphytica 184:289-299, doi: 10.1007/ s10681-011-0477-z.

Crespel, L., M. Sigogne, N. Donés, D. Relion, and P. Morel. 2013. Identification of relevant morphological, topological and geometrical variables to characterize the architecture of rose bushes in relation to plant shape. Euphytica 191:129-140, doi: 10.1007/s10681-013-0902-6.

Dirr, M.A. 2004. Hydrangeas for American gardens. Timber Press, Portland, OR.

Dirr, M.A., O.M. Lindstrom, Jr., R. Lewandowski, and M.J. Vehr. 1993. Cold hardiness estimates of woody taxa from cultivated and wild collections. J. Environ. Hortic. 11:200-203.

Dixon, A.G.O., J.M. Ngeve, and E.N. Nukenine. 2002. Genotype $\times$ environment effects on severity of cassava bacterial blight disease caused by Xanthomonas axonopodis pv. manihotis. Eur. J. Plant Pathol. 108:763-770.

Hagan, A.K. and J. M. Mullen. 2001. Diseases of Hydrangea. Alabama Cooperative Extension System, Alabama A\&M And Auburn Univ., 1-8.

Halcomb, M. and S. Reed. 2012. Hydrangea production. Univ. of Tennessee Extension Publication.

Hayes, R.J., M.A. Trent, B. Mou, I. Simko, S.J. Gebben, and C.T. Bull. 2014. Baby leaf lettuce germplasm enhancement: Developing diverse populations with resistance to bacterial leaf spot caused by Xanthomonas campestris pv. vitians. HortScience 49:18-24.

Hurme, P., T. Repo, O. Savolainen, and T. Pääkkönen. 1997. Climatic adaptation of bud set and frost hardiness in Scots pine (Pinus sylvestris). Can. J. For. Res. 27:716-723, doi: 10.1139/cjfr-27-5-716.

Li-Marchetti, C., C. Le Bras, A. Chastellier, D. Relion, P. Morel, S. Sakr, L. Oyant HibrandSaint, and L. Crespel. 2017. 3D phenotyping and QTL analysis of a complex character: Rose bush architecture. Tree Genet. Genomes 13: doi: 10.1007/s11295-017-1194-0.

Maas, J.L., C. Gouin-Behe, J.S. Hartung, and S.C. Hokanson. 2000. Sources of resistance for two differentially pathogenic strains of Xanthomonas fragariae in Fragaria genotypes. HortScience 35:128-131.

McNamara, S. and S.C. Hokanson. 2010. Cold hardiness of weigela (Weigela florida Bunge) cultivars. J. Environ. Hortic. 28:35-40.

McNamara, S., H. Pellett, M. Florkowska, and O. Lindstrom. 2002. Comparison of the cold hardiness of landscape tree and shrub cultivars growing at two disparate geographic locations. J. Environ. Hortic. 20:77-81.

Mmbaga, M.T. and J.B. Oliver. 2007. Effect of biopesticides on foliar diseases and japanese beetle (Popillia japonica) adults in roses (Rosa spp.), oakleaf hydrangea (Hydrangea quercifolia), and crapemyrtle (Lagerstroemia indica). Arboric. Urban For. 33:210-219.

Moles, A.T., D.I. Warton, L. Warman, N.G. Swenson, S.W. Laffan, A.E. Zanne, A. Pitman, F.A. Hemmings, and M.R. Leishman. 2009. Global patterns in plant height. J. Ecol. 97:923-932, doi: 10.1111/ j.1365-2745.2009.01526.x.

Naqvi, S.F., M. Inam-ul-Haq, M.I. Tahir, and S.M. Mughal. 2012. Screening of sesame germplasm for resistance against the bacterial blight caused by Xanthomonas campestris pv. sesami. Pak. J. Agric. Sci. 49:131-134.

Pagter, M., J.F. Hausman, and R. Arora. 2011a. Deacclimation kinetics and carbohydrate changes in stem tissues of Hydrangea in response to an experimental warm spell. Plant Sci. 180: 140-148, doi: 10.1016/j.plantsci.2010.07.009.

Pagter, M., A. Kristoffersen, P. Brønnum, and M. Jensen. 2010. Phenotypic differences in development of cold hardiness in three latitudinal populations of Acer platanoides L. Scand. J. For. Res. 25:412-420, doi: 10.1080/02827581. 2010.512872.

Pagter, M., I. Lefèvre, R. Arora, and J.F. Hausman. 2011b. Quantitative and qualitative changes in carbohydrates associated with spring deacclimation in contrasting Hydrangea species. Environ. Exp. Bot. 72:358-367, doi: 10.1016/j.envexp bot.2011.02.019.

Pagter, M. and M. Williams. 2011. Frost dehardening and rehardening of Hydrangea macrophylla stems and buds. HortScience 46:1121-1126, doi: 10.5344/ajev.2016.16078.

Pounders, C.T., E.K. Blythe, D.C. Fare, G.W. Knox, and J.L. Sibley. 2010. Crapemyrtle genotype $\mathrm{x}$ environment interactions, and trait stability for plant height, leaf-out, and flowering. HortScience 45:198-207.

R Core Team. 2018. R: A language and environment for statistical computing. R Foundation for Statistical Computing, Vienna, Austria. $<$ https://www.R-project.org/>.

Reed, S.M. 2000. Compatibility studies in Hydrangea. J. Environ. Hort. 18:29-33.

Reed, S.M. 2004. Self-incompatibility and time of stigma receptivity in two species of Hydrangea. HortScience 39:312-315.

Reed, S.M. 2010. 'Ruby Slippers' and 'Munchkin' oakleaf hydrangeas. HortScience 45:1908-1909.

Reed, S.M. and L.W. Alexander. 2015. 'Queen of Hearts' oakleaf hydrangea. HortScience 50: 310-311.

Roach, J.A., S. Verma, N.A. Peres, A.R. Jamieson, W.E. van de Weg, M.C.A.M. Bink, N.V. Bassil, S. Lee, and V.M. Whitaker. 2016. FaRXf1: A locus conferring resistance to angular leaf spot caused by Xanthomonas fragariae in octoploid strawberry. Theor. Appl. Genet. 129: 1191-1201, doi: 10.1007/s00122-016-2695-1.

Suojala, T. and L. Lindén. 1997. Frost hardiness of Philadelphus and Hydrangea clones during ecodormancy. Acta Agr. Scand. 47:58-63, doi: 10.1080/09064719709362440. 
USDA Plant Hardiness Zone Map. 2012. Agricultural Research Service, U.S. Department of Agriculture. Accessed from https://planthardiness.ars.usda.gov/.

Van Iersel, M.W. and K.S. Nemali. 2004. Drought stress can produce small but not compact marigolds. HortScience 39(6):1298-1301.

Van Laere, K., I. Kirov, J. Van Huylenbroeck, and L. Khrustaleva. 2018a. Cytogenetic approaches enhance advanced breeding in woody ornamental species. Acta Hort. 1191:9-16, doi: 10.17 660/ActaHortic.2018.1191.2.

Van Laere, K., S.C. Hokanson, R. Contreras, and J. Van Huylenbroeck. 2018b). Woody ornamentals of the temperate zone. In: J. Van Huylenbroeck (ed.). Ornamental crops. Handbook of plant breeding, vol 11. Springer, Cham,
Switzerland. https://doi-org.ezp2.lib.umn.edu/ 10.1007/978-3-319-90698-0_29.

Ye, Y., M. Cai, Y. Ju, Y. Jiao, L. Feng, H. Pan, and T. Cheng. 2016. Identification and validation of SNP markers linked to dwarf traits using SLAF-seq technology in Lagerstroemia PLoS One 11:e0158970, doi: 10.1371/journal. pone. 0158970 . 